\title{
Influence of Cowpea Mottle Virus and Cucumber Mosaic Virus on the Growth and Yield of Six Lines of Soybean (Glycine Max L.)
}

\author{
Olawale Arogundade (Corresponding author) \\ Fruit Research Programme, National Horticultural Research Institute \\ Idi Isin, PMB 5432, Ibadan, Nigeria \\ Tel: 234-8055-360425 E-mail: arogundade_olawale@yahoo.co.uk \\ Olusegun Samuel Balogun \\ Department of Crop Protection, Faculty of Agriculture, University of Ilorin \\ PMB 1515, Ilorin, Kwara State, Nigeria \\ Tel: 234-803-581-4131_E-mail: Samcleo1@yahoo.com \\ Olumide Shokalu \\ Soybean Research Programme, National Cereal Research Institute \\ Badeggi, PMB 8, Niger State, Nigeria \\ Tel: 234-806-062-6265Ｅ-mail: olushokalu@yahoo.co.uk \\ Taiye Hussein Aliyu \\ Department of Crop Protection, Faculty of Agriculture \\ University of Ilorin, PMB 1515, Ilorin, Kwara State, Nigeria \\ Tel: 234-803-047-2667 E-mail: aliyutaiyehussein@yahoo.com
}

\begin{abstract}
Cowpea mottle virus is of localised importance on cowpea in Nigeria infecting several leguminous species and Cucumber mosaic virus is of worldwide distribution infecting several horticultural crops.

A study was carried out in the screen house of the crop production pavilion, Faculty of Agriculture, University of Ilorin, Ilorin, Kwara State, Nigeria to determine the pathogenic response of six lines of soybean (TGx 1844-18E, TGx 1448-2E, TGx- 1910-8F, TGx 1019-2EN, TGx 1844-4E and TGx 1876-4E) to single and mixed infection with cowpea mottle virus $(\mathrm{CMeV})$ and cucumber mosaic virus $(\mathrm{CMV})$. The Lines obtained from National Cereal Research Institute, Badeggi were used for the experiment.

Two viable Seeds were sown per 4litre plastic pots filled with sterilized soil; inoculation of viral isolates was carried out mechanically on the soybean at two weeks after planting.

The results revealed that all Soybean lines tested were susceptible to single and mixed infection of the two viruses. However the tolerance level of the legumes, as shown by the percentage loss in selected growth and yield attributes indicated that line TGx $1910-8 \mathrm{~F}$ is the most tolerant while TGx $1844-18 \mathrm{E}$ is the most susceptible to single and mixed infection.
\end{abstract}

Hence, TGx 1910-8F is most suitable in areas where there is an outbreak of disease caused by CMeV and CMV.

Keywords: Glycine max, Horticultural crops, Leguminous species, Outbreak, Susceptible, Tolerance

\section{Introduction}

Soybean is an annual grain legume that varies in growth habit and height. It may grow prostrate, not growing higher than $20 \mathrm{~cm}$, or even up to 2 meters in height (IITA Report, 2007). It plays an important role in the nutrition of people in 
developing countries of the tropics and subtropics, especially in sub-Saharan Africa, Asia Central and South America. Due to its high quality and inexpensive protein content, this is about $40 \%$ of the seed (Weingarther, 1987). The oil and protein contents in soybean together account for about $60 \%$ of dry soybean seed by weight, protein at $40 \%$ and oil at $20 \%$. The remainder consists of $35 \%$ carbohydrate and about $5 \%$ ash. The oil is high in essential fatty acids, devoid of cholesterol and constitutes more than $50 \%$ of the world's edible vegetable oil in trade (Ogundipe and Weingatner, 1992).

Increasing demand for edible oil proteins in developing countries has led to the recent expansion of soybeans production in Nigeria. Many varieties have since been produced by introduction, breeding and selection and with the outstanding ones released for large scale production in different ecological zones (Dashiell and Root, 1985). According to Baten et al. (1992), soybean was the world's most important grain legume crop in terms of total production, consumption and international trade. The IITA report (2007) puts the total land area under soybean in the world at 95.2million ha and total production at 212.6million tonnes.

The three major soybean producing countries as at 2005 were USA (29million ha), Brazil (23million ha), and Argentina (14million ha). In terms of total production, USA produced 83million tones, followed by Brazil (52million tones, and Argentina (38million tons). While in Africa, soybean was grown on an average of 1.16 million ha with an average production of 1.26 million tones in 2005 . African countries with the largest area of production were Nigeria $(601,000 \mathrm{ha})$, South Africa (150.000ha) Uganda (144000 ha), Malawi (68,000 ha) (FAO report, 2005).

Soybean cultivation has become well-established in several areas of the Southern Guinea Savanna Zone (SGSZ) like Benue, Niger, Kaduna, which are currently the major commercial soybean producing areas in Nigeria.

In Nigeria, a number of diseases have been reported on the soybean crop. These includes: Cercospora leafspot, bacteria blight, red leaf blotch, crown rot and soybean mosaic virus (Akem, 1996). The latest disease on soybean in the country is rust (Shokalu et al., 2000). Soybean mosaic virus (SMV) is the most frequently isolated virus of soybean, it probably occurs wherever soybean is grown, the symptoms vary according to the particular viral strain, host genotype, weather and time of infection (Sinclair and Shurtleff, 1975). Cowpea mild mottle virus (CMMV) has been reported on soybean from Nigeria (IITA, 1980; Anno Nyako, 1984). Cowpea mottle virus is of localized importance on cowpea in Nigeria (Kareem and Taiwo, 2007). The objectives of this study were to evaluate the response of some soybean cultivars in Nigeria to infection singly with cowpea mottle virus and to determine their tolerance rating

\section{Materials and Methods}

Isolates of Cowpea mottle virus were obtained from the International Institute of Tropical Agriculture (IITA), Ibadan, Nigeria. Six Soybean lines; TGx 1844-18E, TGx 1448-2E, TGx- 1910-8F, TGx 1019-2EN, TGx 1844-4E and TGx 1876-4E obtained from IITA, Ibadan were used for the study.

In the screen house, perforated plastic pots where filled with sandy loam soil obtained behind the crop production pavilion, Faculty of Agriculture, University of Ilorin. The soil was steam sterilized to eliminate any soil inhibiting micro organisms and enriched with 15:15:15 NPK fertilizer. Two seeds each of the Soybean lines were sown in separate pots in December 2007. The pots were arranged in a randomised complete block design with three replications and a total of 72 pots were utilized for the study. The seedlings were constantly watered and weeds removed manually as they emerge.

The $\mathrm{CMeV}$ and $\mathrm{CMV}$ extracts were extracted from infected leaves obtained from the stock of the plant Virology Laboratory at the International Institute for Tropical Agriculture (IITA). Infected leaf samples were macerated in phosphate buffer ( $\mathrm{pH} 7.2)$ at the rate of $1 \mathrm{~g} / 5 \mathrm{ml}$ of buffer in pre-cooled mortar and pestle. The inoculation was done by mechanical transmission of virus through sap. The sap was applied on the surfaces of the oldest leaves previously dusted which carborundum. The sap was applied by rubbing the leaves gently with a cotton wool dipped in the sap. Inoculated plants were rinsed thereafter with water. Plants that were mocked-inoculated with buffer only served as control. Inoculation was done two weeks after planting with single and mixed infection consisting of CMeV, CMV and $\mathrm{CMeV}+\mathrm{CMV}$.

Data were collected at the time of infection as well as on weekly basis. Plant height and number of leaves were taken weekly over a period of 9 weeks after inoculation. Yield parameter such as number of pods, dry weight of pods and dry weight of grain were also taken. The pods were harvested, sun dried to about $12 \%$ moisture content and weighed with the aid of an electronic balance. The pods were threshed manually and weighed. All data were subjected to analysis of variance having regards for the factorial nature of the treatment design and the significant differences between them were determined at $\mathrm{P}<0.05$, using the new Duncan's Multiple Range Test.

The lines were rated for tolerance based on the mean losses incurred in selected growth and yield attributes of infected plants compared to the non -infected plants of the same variety. Following Balogun and Bakare rating (2007), the scales used include $0-15 \%$ loss----Very tolerant; $16-30 \%$ loss----Moderately tolerant; $31-50 \%$ loss ----Mildly tolerant; $51-100 \%$ loss ----very susceptible. 


\section{Results}

The six lines used for the experiment showed symptomatic response to infection by Cowpea mottle virus $(\mathrm{CMeV})$ and Cucumber mosaic virus (CMV) under single and mixed infection situations but to seemingly different extent.

In susceptible lines, infection with $\mathrm{CMeV}$ manifested as leaf mottling, which progressed to leaf wrinkling. Such leaves appeared relatively smaller in size than normal leaves. Generally, plants that were susceptible to infection with CMV alone manifested only mild mosaic symptoms while those plants that were susceptible to mixed infection with CMV and $\mathrm{CMeV}$ showed a combination of mosaic, necrosis and stunting as was also observed in severe $\mathrm{CMeV}$ infections (Plate 1). It was observed that $\mathrm{CMeV}$ induced striking symptoms even on the fruit setting and the fruits of severely infected plants. Plate 2 shows Soybean line TGx 1019-2EN manifesting serious distortions on the fruit set. All mocked inoculated control plants were free from the infections and had a normal fruit set as shown in plate 3 .

The main effect of variety and inoculation on growth parameters as at 7 weeks after inoculation as shown (table 1), ranging from week 2 through week 7 after inoculation, viral inoculated plants were generally significantly shorter than the healthy control. However, there were no significant differences between inoculated plants until the $6^{\text {th }}$ and $7^{\text {th }}$ week. Even then, those inoculated singly with cowpea mottle virus and those inoculated with a mixture of cowpea mottle virus and cucumber mosaic virus were not significantly different. Consideration of the different treatment combinations showed that the soybean plants responded in various ways to the different inoculation regimes (Treatments). It is apparent however that those plants inoculated with $\mathrm{CMeV}$ were the most severely affected.

In the number of leaves, analysis of the main effect of inoculation (i.e. regardless of the variety involved) shows that there were generally significant differences at $\mathrm{p}<0.05$ between the viral inoculated soybean plants from week 2 through week 5 after inoculation. However, there were no significant differences between the control and CMV inoculated plants at $4^{\text {th }}, 6^{\text {th }}$ and $7^{\text {th }}$ week after inoculation. There was no significant difference between all treatments including the control at week 8 as shown in Table 2 .

\subsection{Effects on yield parameters}

Table 3 shows the main effect of variety and inoculation on number of pods, weight of grains and weight of grains. As with the growth parameters, analysis of variance shows that the yield parameters in mock inoculated plants significantly differed from those in viral inoculated ones with mock inoculated plants having higher values compared to the viral inoculated ones.

\subsection{Tolerance and susceptibility rating}

Considering the level of tolerance and susceptibility to the diseases by the soybeans lines as shown in table 4, TGx 1910-8F, TGx 1844-4E \& TGx 1876-4E showed levels of tolerance to both single and mix infection while TGx 1019-2EN and TGx 1844-18E showed levels of susceptibility to both single and mix infection of CMeV and CMV.

\section{Discussion}

Recently, there has not been a record on the response of soybean cultivars to CMV in this part of the world. However, it has been reported that soybean in this part of the world is susceptible to cowpea mild mottle virus (IITA, 1980; Anno-Nyako, 1984) but nothing had been said about mixed infection of the two viral diseases on soybean.

The experiment showed that all the lines of soybean used are susceptible to CMV, CMeV as well as a mixed infection with $\mathrm{CMeV}$ and CMV. The study showed that soybean lines; TGX 1844-18E and TGX 1019-2EN are highly susceptible to cowpea mottle virus as they expressed some symptoms showing deviation from the normal state of the plant physiology. Symptoms include stunting, mosaic pattern, mottling of the leaves and malformed leaves structures. Plants inoculated with CMV did not cause development of visible symptoms on some of the tested soybean cultivars. Smith (1992) had also observed that CMV does not normally cause visible symptoms on Soybean. The soybean plants under mixed infection with $\mathrm{CMV}$ and $\mathrm{CMeV}$ showed symptoms similar to those manifested by plants under $\mathrm{CMeV}$ alone. This could be as a result of the effect of the $\mathrm{CMeV}$ in the combination. It was also an indication that the combination of the two viruses was not synergistic in the soybean cultivars.

\section{References}

Akem, C.N. (1996). Management of soybean disease. International Institute for Tropical Agriculture (IITA). Research Guide 40.

Anno Nyako, F.O. (1984). Identification, partial characterization and some properties of a virus causing a mild mottle disease in Glycine $\max (\mathrm{L})$ Merril in Nigeria and the Evaluation of local and exotic cowpeas (Vigina unguiculata (L) Walp) for grain legume viruses under natural conditions in Kumasi, Ghana.

Balogun, O.S., \& Bakare, R.A. (2007). Evaluation of the pathogenic response of some Okra lines to Cucumber Mosaic Virus. Journal of Agricultural Research and Development, 6: 63- 74. 
Baten, M. A., Agboola, A. A., \& Mutsears H. J. W. (1992). An exploratory survey of soybean production in Aiyepe. Nigeria pages 333-342 in: K. Mulongoy, M. Gueye and O.S.C Spencer (eds) Biological Nitrogen Fixation and sustainability of tropical Agriculture Wiley Spryce co-publication.

Dashiell, K.E., \& Root, W. R. (1985). Reports of 1984. Naturally coordinated Research project on soybean. IITA Ibadan $70-120$.

FAO Publication. (2005). [Online] Available: www.earthpolicy.org/Books/PB2/PB2ch9_ss4.htm - 29k.

IITA. (1980). Annual Report Ibadan Nigeria IITA, 136p.

IITA. (2007). Annual Report Ibadan Nigeria. [Online] Available: www.iita.org $/ \mathrm{cms} /$ details $/ \mathrm{a}=1219 \& \mathrm{z}=81 \&$ template=news_details.aspx-16k.

Kareem, K.T., \& Taiwo, M.A. (2007). Interactions of viruses in cowpea: Effects on growth and yield parameters. Virology journal, 4:15

Ogundipe, H.O., \& Weingartner, K. (1992). Effect of the addition of soybean on the nutritional status of selected traditional Nigerian foods. Tropical Oilseed J., 67-73

Shokalu, O., Idowu, A.A., \& Misari, S. M. (2000). Prevalence of soybean rust in south-western Nigeria. Tropical Oilseed Journal, 5: 79-81

Sinclair, J.B., and Schurtleff, M. C. (1975). Compendium of soybean disease St. paul, Minnesota. America Phytopathological society.

Smith K.M. (1992). A text book of plant viral Disease. $3^{\text {rd }}$ edition. Academic press New York.

Weingartner, K.E. (1987). Processing, nutrition and utilization of soybean. Pages 149-174 In S.R Singh, K.O Rachie and K.E Dashiell (eds) Soybean for the tropics. John Wiley and sons. New York.

Table 1. Effect of variety and viral inoculation on the height of soybean at different times after inoculation

Weeks after inoculation

\begin{tabular}{lllllllll}
\hline Variety & $\mathbf{0}$ & $\mathbf{1}$ & $\mathbf{2}$ & $\mathbf{3}$ & $\mathbf{4}$ & $\mathbf{5}$ & $\mathbf{6}$ & $\mathbf{7}$ \\
\hline TGx 1910-8F & $6.2 \mathrm{~h}$ & $9.0 \mathrm{hi}$ & $13.6 \mathrm{f}$ & $21.6 \mathrm{efg}$ & $31.2 \mathrm{cde}$ & $40.5 \mathrm{bcd}$ & $52.8 \mathrm{a}$ & $55.6 \mathrm{a}$ \\
TGx 1448-2E & $10.0 \mathrm{de}$ & $12.3 \mathrm{de}$ & $16.3 \mathrm{cde}$ & $22.6 \mathrm{def}$ & $27.3 \mathrm{ef}$ & $29.3 \mathrm{~g}$ & $34.3 \mathrm{cde}$ & $36.9 \mathrm{de}$ \\
TGx1844-18E & $14.8 \mathrm{a}$ & $17.2 \mathrm{a}$ & $20.6 \mathrm{~b}$ & $28.6 \mathrm{bc}$ & $33.2 \mathrm{bcd}$ & $42.2 \mathrm{~d}$ & $50.7 \mathrm{a}$ & $54.4 \mathrm{a}$ \\
TGx 1844-4E & $9.1 \mathrm{ef}$ & $11.5 \mathrm{def}$ & $17.5 \mathrm{c}$ & $24.1 \mathrm{de}$ & $31.2 \mathrm{cde}$ & $41.8 \mathrm{bc}$ & $48.8 \mathrm{a}$ & $50.7 \mathrm{ab}$ \\
TGx 1019-2EN & $8.2 \mathrm{fg}$ & $11.2 \mathrm{efg}$ & $15.5 \mathrm{cdef}$ & $22.6 \mathrm{def}$ & $25.3 \mathrm{f}$ & $29.3 \mathrm{~g}$ & $32.8 \mathrm{def}$ & $36.3 \mathrm{de}$ \\
TGx 1876-4E & $5.6 \mathrm{~h}$ & $8.2 \mathrm{i}$ & $13.4 \mathrm{f}$ & $20.3 \mathrm{fg}$ & $29.4 \mathrm{cdef}$ & $46.9 \mathrm{a}$ & $56.4 \mathrm{a}$ & $64.2 \mathrm{a}$ \\
S. E & 0.37 & 0.40 & 0.67 & 1.08 & 1.75 & 1.43 & 1.57 & 1.50 \\
Viral Treatment & & & & & & & & \\
CMeV & & & & & & & & \\
CMV & $9.7 \mathrm{~b}$ & $12.9 \mathrm{a}$ & $17.5 \mathrm{~b}$ & $24.1 \mathrm{~b}$ & $30.8 \mathrm{~b}$ & $36.5 \mathrm{~b}$ & $39.7 \mathrm{c}$ & $40.8 \mathrm{c}$ \\
CMeV + CMV & $9.3 \mathrm{~b}$ & $11.9 \mathrm{~b}$ & $16.8 \mathrm{~b}$ & $24.5 \mathrm{~b}$ & $31.2 \mathrm{~b}$ & $38.1 \mathrm{~b}$ & $43.1 \mathrm{~b}$ & $43.7 \mathrm{~b}$ \\
Control & $9.8 \mathrm{~b}$ & $12.4 \mathrm{~b}$ & $19.0 \mathrm{a}$ & $28.9 \mathrm{~b}$ & $30.4 \mathrm{~b}$ & $36.3 \mathrm{~b}$ & $39.8 \mathrm{c}$ & $41.7 \mathrm{c}$ \\
S. E & 0.18 & 0.20 & 0.32 & 0.52 & 0.85 & 0.70 & 0.76 & 0.73
\end{tabular}

Means followed by the same letter(s) are not significantly different at $\mathrm{P}<0.05$ using the new Duncan's multiple range test 
Table 2. Effect of variety and viral inoculation on number of leaves of soybean at different times after inoculation

Weeks after inoculation

\begin{tabular}{lllllllllll}
\hline Variety & 0 & 1 & 2 & 3 & 4 & 5 & 6 & 7 & 8 & 9 \\
\hline TGx 1910-8F & $2.1 \mathrm{f}$ & $3.2 \mathrm{~cd}$ & $4.5 \mathrm{a}$ & $6.7 \mathrm{a}$ & $8.0 \mathrm{a}$ & $8.4 \mathrm{~b}$ & $9.2 \mathrm{bc}$ & $8.8 \mathrm{~b}$ & $9.0 \mathrm{~b}$ & $8.6 \mathrm{~b}$ \\
TGx 1448-2E & $2.3 \mathrm{ef}$ & $3.0 \mathrm{de}$ & $3.9 \mathrm{cdef}$ & $5.4 \mathrm{cdef}$ & $6.2 \mathrm{efg}$ & $7.3 \mathrm{c}$ & $7.8 \mathrm{de}$ & $7.7 \mathrm{~cd}$ & $7.8 \mathrm{~cd}$ & $6.9 \mathrm{~cd}$ \\
TGx1844-18E & $2.0 \mathrm{f}$ & $3.0 \mathrm{de}$ & $3.9 \mathrm{cdef}$ & $5.8 \mathrm{ccde}$ & $6.3 \mathrm{def}$ & $7.3 \mathrm{c}$ & $8.2 \mathrm{~cd}$ & $7.8 \mathrm{~cd}$ & $7.5 \mathrm{~cd}$ & $6.7 \mathrm{~cd}$ \\
& & & & & & & & & $\mathrm{e}$ & \\
TGx 1844-4E & $2.6 \mathrm{~cd}$ & $3.0 \mathrm{de}$ & $3.9 \mathrm{cdef}$ & $5.2 \mathrm{def}$ & $6.7 \mathrm{cde}$ & $8.1 \mathrm{~b}$ & $9.8 \mathrm{~b}$ & $8.2 \mathrm{bc}$ & $8.6 \mathrm{bc}$ & $7.4 \mathrm{bc}$ \\
& & & & & & & & & & $\mathrm{d}$ \\
TGx1019-2EN & $2.3 \mathrm{ef}$ & $3.2 \mathrm{~cd}$ & $3.9 \mathrm{cdef}$ & $5.2 \mathrm{def}$ & $5.4 \mathrm{~g}$ & $5.7 \mathrm{e}$ & $7.6 \mathrm{def}$ & $7.3 \mathrm{~cd}$ & $7.5 \mathrm{~cd}$ & $7.1 \mathrm{~cd}$ \\
TGx1876-4E & $2.0 \mathrm{f}$ & $3.0 \mathrm{de}$ & $4.0 \mathrm{cdef}$ & $5.5 \mathrm{bcdef}$ & $7.0 \mathrm{bcd}$ & $9.8 \mathrm{a}$ & $11.0 \mathrm{a}$ & $12.0 \mathrm{a}$ & $13.0 \mathrm{a}$ & $10.9 \mathrm{a}$ \\
S.E & 0.08 & 0.06 & 0.12 & 0.20 & 0.25 & 0.22 & 0.33 & 0.33 & 0.37 & 0.40 \\
Viral Treatment & & & & & & & & & & \\
& & & & & & & & & & \\
CMeV & $2.5 \mathrm{a}$ & $3.0 \mathrm{~b}$ & $3.7 \mathrm{c}$ & $5.4 \mathrm{~b}$ & $6.5 \mathrm{~b}$ & $7.2 \mathrm{~b}$ & $7.5 \mathrm{~b}$ & $7.5 \mathrm{~b}$ & $7.6 \mathrm{a}$ & $6.8 \mathrm{a}$ \\
CMV & $2.5 \mathrm{a}$ & $3.1 \mathrm{~b}$ & $4.0 \mathrm{~b}$ & $5.6 \mathrm{~b}$ & $6.8 \mathrm{ab}$ & $7.4 \mathrm{~b}$ & $8.3 \mathrm{a}$ & $7.6 \mathrm{ab}$ & $7.1 \mathrm{a}$ & $6.0 \mathrm{~b}$ \\
CMeV +CMV & $2.4 \mathrm{~b}$ & $3.1 \mathrm{~b}$ & $3.9 \mathrm{~b}$ & $5.4 \mathrm{~b}$ & $6.5 \mathrm{~b}$ & $7.3 \mathrm{~b}$ & $7.5 \mathrm{~b}$ & $7.4 \mathrm{~b}$ & $7.4 \mathrm{a}$ & $5.9 \mathrm{~b}$ \\
Control & $2.5 \mathrm{ab}$ & $3.5 \mathrm{a}$ & $4.5 \mathrm{a}$ & $6.1 \mathrm{a}$ & $7.1 \mathrm{a}$ & $7.8 \mathrm{a}$ & $8.1 \mathrm{a}$ & $8.0 \mathrm{a}$ & $7.6 \mathrm{a}$ & $6.1 \mathrm{~b}$ \\
S.E & 0.04 & 0.03 & 0.06 & 0.10 & 0.12 & 0.10 & 0.16 & 0.16 & 0.18 & 0.19
\end{tabular}

$\overline{\text { Means followed by the same letter(s) are not significantly different at } \mathrm{P}<0.05 \text { using the new Duncan's multiple range }}$ test

Table 3. Effect of variety and viral inoculation on yield parameters

\begin{tabular}{lccc}
\hline Variety & No. of pods & Dry weight of pods (g) & $\begin{array}{c}\text { Dry weight of grains } \\
\text { (g) }\end{array}$ \\
\hline TGx $1910-8 \mathrm{~F}$ & $19.8 \mathrm{a}$ & $5.2 \mathrm{a}$ & $3.9 \mathrm{a}$ \\
TGx $1448-2 \mathrm{E}$ & $14.7 \mathrm{c}$ & $4.4 \mathrm{abc}$ & $2.9 \mathrm{abc}$ \\
TGx $1844-18 \mathrm{E}$ & $8.3 \mathrm{~d}$ & $2.8 \mathrm{de}$ & $1.7 \mathrm{f}$ \\
TGx $1844-4 \mathrm{E}$ & $19.3 \mathrm{ab}$ & $5.0 \mathrm{a}$ & $3.8 \mathrm{a}$ \\
TGx1019-2EN & $16.8 \mathrm{abc}$ & $5.0 \mathrm{a}$ & $3.5 \mathrm{a}$ \\
TGx $1876-4 \mathrm{E}$ & $15.4 \mathrm{c}$ & $5.2 \mathrm{a}$ & $3.4 \mathrm{a}$ \\
S.E & 1.09 & 0.35 & 0.22 \\
Viral Treatment & & & \\
& & & \\
CMeV & $10.9 \mathrm{c}$ & $3.1 \mathrm{~b}$ & $1.9 \mathrm{~b}$ \\
CMV & $13.0 \mathrm{~b}$ & $3.6 \mathrm{~b}$ & $2.1 \mathrm{~b}$ \\
CMeV + CMV & $12.3 \mathrm{~b}$ & $3.2 \mathrm{~b}$ & $1.9 \mathrm{~b}$ \\
Control & $18.1 \mathrm{a}$ & $6.7 \mathrm{a}$ & $5.3 \mathrm{a}$ \\
S.E & 0.53 & 0.17 & 0.10 \\
\hline
\end{tabular}

Means followed by the same letter(s) are not significantly different at $\mathrm{P}<0.05$ using the new Duncan's multiple range test 
Table 4. Comparative percentage losses in soybean varieties under single and mixed infection

\begin{tabular}{llllllll}
\hline Variety & $\begin{array}{c}\text { Infection } \\
\text { type }\end{array}$ & \multicolumn{9}{c}{ Percentage losses* } & \multicolumn{2}{c}{$\begin{array}{c}\text { Tolerance/susceptibil } \\
\text { ity rating }\end{array}$} \\
\cline { 3 - 8 } & & $\begin{array}{c}\text { Grain } \\
\text { Wt }\end{array}$ & Pod Wt & $\begin{array}{c}\text { Leaf } \\
\text { area }\end{array}$ & $\begin{array}{c}\text { Final } \\
\text { Ht }\end{array}$ & $\begin{array}{c}\text { Mean } \\
\text { Cum. }\end{array}$ & \\
& & & & & & Loss & \\
\hline TGx1910-8F & Single & 60.5 & 43.1 & 19.8 & 23.5 & 36.7 & Mildly Tolerant \\
& Mix & 45.6 & 25.0 & 16.2 & 21.2 & 27.0 & Moderately Tolerant \\
TGx1448-2E & Single & 79.5 & 70.0 & 37.6 & 28.7 & 53.9 & Very susceptible \\
& Mix & 65.2 & 41.3 & 38.5 & 19.5 & 41.1 & Mildly Tolerant \\
TGx1844-4E & Single & 50.0 & 35.7 & 22.9 & 13.5 & 30.5 & Moderately tolerant \\
& Mix & 50.9 & 42.9 & 19.1 & 9.5 & 30.6 & Moderately tolerant \\
TGx1019-2EN & Single & 75.9 & 66.8 & 37.3 & 28.7 & 52.2 & Very susceptible \\
& Mix & 69.6 & 61.2 & 37.1 & 28 & 51.3 & Very susceptible \\
TGx1876-4E & Single & 68.4 & 62.1 & 8.1 & 5.3 & 36.0 & Mildly Tolerant \\
& Mix & 63.2 & 48.4 & 27.4 & 21.1 & 40.0 & Mildly Tolerant \\
TGx1844-18E & Single & 79.8 & 74.2 & 63.5 & 49.5 & 66.8 & Very susceptible \\
& Mix & 78.7 & 70.9 & 73.9 & 47.1 & 67.7 & Very susceptible \\
\hline
\end{tabular}

\section{Effect on plant growth}

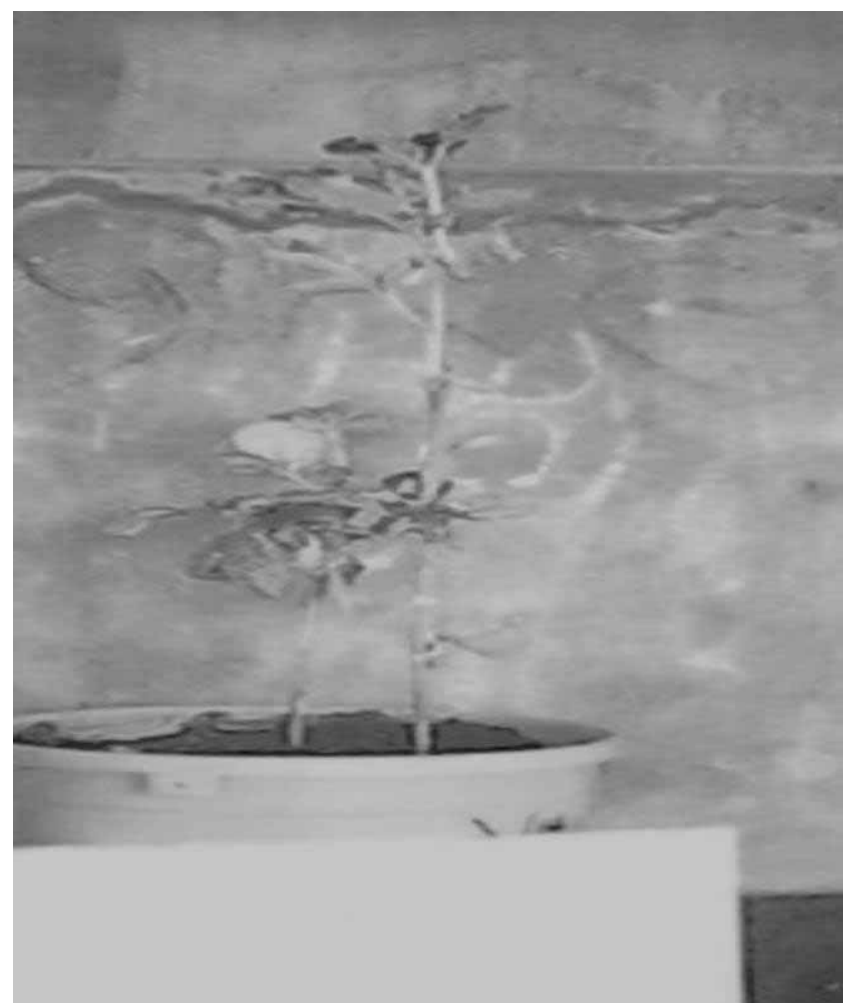

Plate 1. Soybean Soybean line TGx 1019-2 EN under CMeV infection 


\section{Effect on yield attributes}

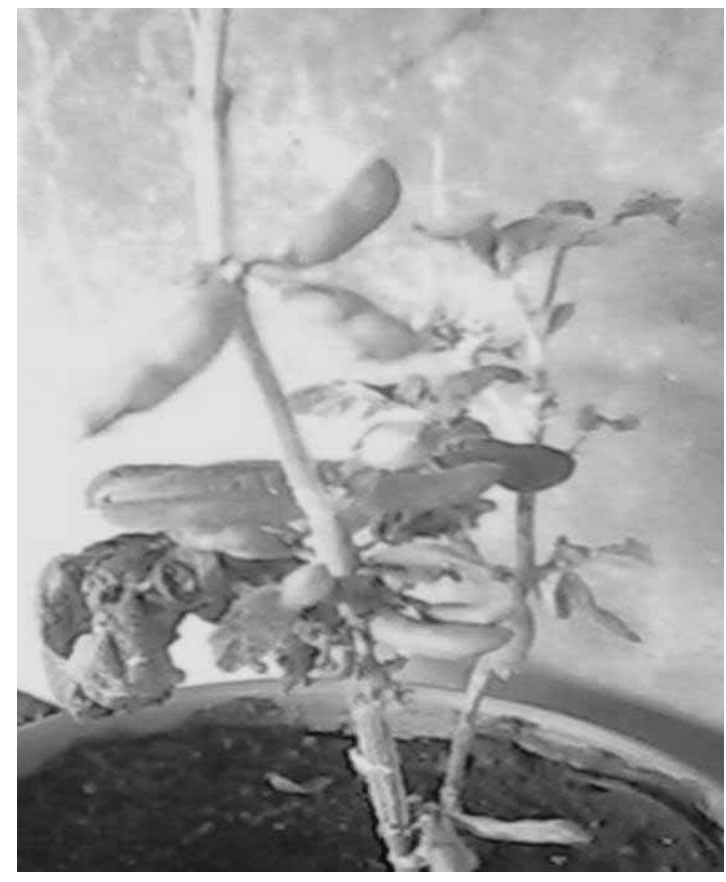

Plate 2

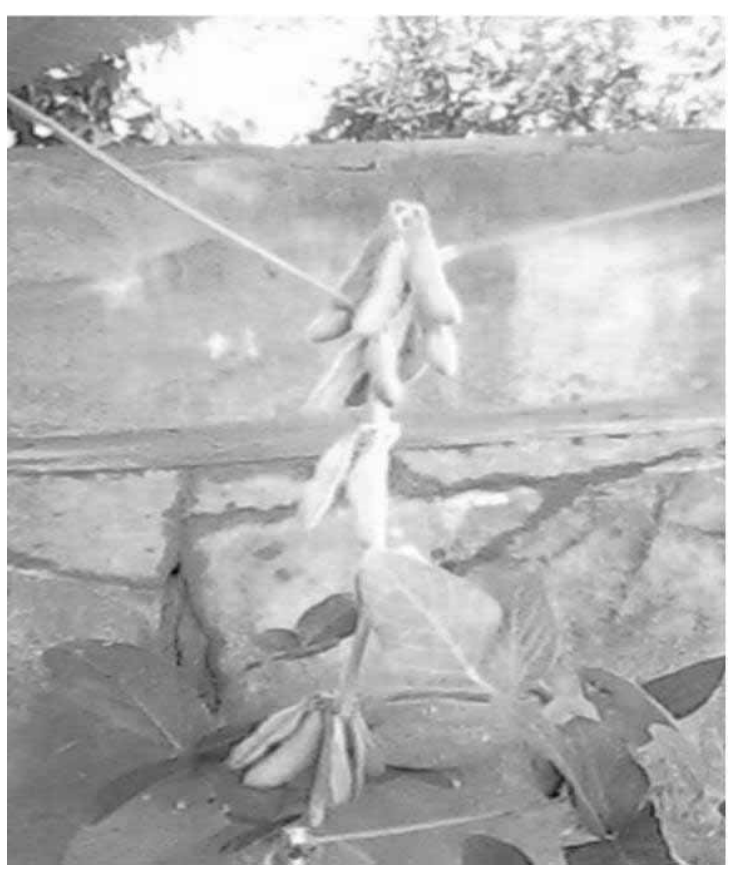

plate3

Comparative fruiting pattern between diseased (Left) and an apparently healthy soybean plant (Right). 